\title{
The Boro Intelligentsia: It's Role in the Change and Transformation of the Boro Society
}

\author{
Dr. Bijoy Daimary ${ }^{1}$ \\ (Associate Professor, Department of History, Union Christian College, Barapani, Meghalaya)
}

\begin{abstract}
Scholars of ethnicity and nationalism observe that a society undergoing modernization and industrialization creates alongside a class of elites which takes major decisions bringing change and transformation in the society. In the multi-ethnic societies, spurring of elites involve inter and intra elite competitions for the sharing of the developments and fewer employment opportunities. The growth and development of an ethnic community often depends on the situations around and the kind of inter elite competition they are pressed into. The Boro society too began undergoing modernization with the spread of modern education in the early decades of the $20^{\text {th }}$ century. In the beginning they were meagre in number, but as time passed by, they grew in number and strength and by 1930s they emerged as one of the formidable political force of the state proving themselves as the king makers of that time. As saying goes, intellectual revolution precedes political revolution; the Boro intelligentsia of the early decades of the $20^{\text {th }}$ century was also more concerned with bringing an intellectual awakening among the members of the Boro community.
\end{abstract}

Key words: Ethnicity, elites, multi-ethnic, spurring, meagre, intelligensia, awakening.

Accepted Date: 24 June 2013

\section{Introduction}

In the opinion of the elitist theorists, a society may be better explained in the context of its class composition. They have observed the presence of personalities, groups or classes in every society, which mobilize the masses into particular ideology or take major decisions which have significant impact on the development of the ethnic communities. These personalities, classes or groups have been named differently in different situations. Antonio Gramci terms them "intellectuals" and "organizers." " On the other occasion, Pareto terms them as the "innovators" and "consolidators" of the society. Schumpeter's "entrepreneurs" and "modern capitalists" may be called innovators in Pareto's phraseology. ${ }^{2}$ Both Mosca and Pareto, recognize the existence of "Governing elite" or "political class" as distinct groups which have strong influence over the politics. ${ }^{3}$ In other situations, they are referred to as 'leaders' who bring changes in the political and economic situations. Thus, in every society, there has been a 'minority population' who are found taking major decisions which influence the majority of the population. They are called by various names, like 'elites', 'intellectuals', 'leaders', 'politicians', 'middle class' and so on. All these terms are not interchangeable or synonymous. But what implies is that the role of these groups or classes has always been significant in the changing pattern of the society. Social developments, economic transformation and political changes cannot be adequately explained without analyzing the role of such groups or classes. To understand a society, the relation between the elites and the masses needs to be analyzed.

The emergence of the elites is spontaneous and natural in the human society. Every society entering into the terrain of essential functions in the world of economic production creates one or more strata of intellectuals. Their function is not confined only in economic but also in the social and political fields. ${ }^{4}$ According to A Gramci, all men are intellectuals but not all men have function of intellectuals. ${ }^{5}$ Mosca, while making distinction between the elites and the masses observes that in all societies, whether meagerly developed or most advanced one, two classes of people appears, -- a class that rules and a class that is ruled. ${ }^{6}$ Thus, every socio-economic system, alongside itself creates the technicians and organizers or a new culture of a new legal

\footnotetext{
${ }^{1}$. Quinton Hoare \&Geoffrey Nowel Smith (ed), Selection from the prison Notebooks of Antonio Gramci, London, 1971, p.51.

2. L N Sharma, 'The Theories of Elites: Importance and Relevance' in Elites and Development (ed) by Sachinanda \& A K Lal, New Delhi, 1980, p. 11

3. T. B. Bottomore, Elites and Society, Pp. 9-10.

4. A Gramci, op. cit. p. 5

5 Ibid, p. 9.

. T.B. Bottomore, op. cit. p. 9.
} 
system and so forth. ${ }^{7}$ These groups or classes are the organizers of the masses and occupy an intermediate position between the ruler and the ruled. Although the members of this class are often seen to have emerged from the oppressed groups itself, they appear as somewhat independent of both the groups. And hence, they are often called the middle class. The middle class is usually a transient class. ${ }^{8}$ It is transient in the sense that the members of this class may align itself with the ruling class or alternately with the masses, thus making themselves independent and unpredictable.

In the context of India, emergence of the middle class was the outcome of British colonization of the country. The Indian middle class that first emerged were the products of the reforms of the British themselves. They were progressive intellectuals, who were often described as the 'educated middle classes, 'English educated elite', or 'intelligentsia.' They had different social roots. Though a large number was from the British bureaucracy itself, many of them represented the commercial classes, bakers, merchants and landed proprietors as well. ${ }^{10}$ Despite their varied social roots however, the Indian middle class did not represent the interests of their classes or groups, but of India as a whole. ${ }^{11}$ However, the nature and character of the Indian middle class changed in the later period of the British colonization, from progressive to varieties of nationalism. The changed occurred due to the Indian middle class' challenge and response to limited political reforms introduced by the British. In the context of India, the intelligentsia who were at the root of the national movement and the capitalist class are found to be two altogether different groups. Of the two, the former was more influential; as a result, the later had to shape their attitude according to the ideologies of the nationalist movement. ${ }^{12}$

The emergence of the Boro intellectuals, though meager, may be traced far back as in the beginning of the $20^{\text {th }}$ century. They sprang out of a group who acquired English education, little though, and lived just above the toilers. Their social roots lay not in the trade and industry but in the Government services, with predominant connection with land. This was so because the traditional economy did not undergo any transformation even after capitalism had come into the country. The Boro intellectuals of the early decades were meager in development and scanty in number, which however should be seen in the context of social development of this community. In the realm of social science, the term elite or intellectual is studied in specific context. One may be treated as a member of elite or intellectual strata in particular sphere in which one is better in comparison to the rest of one's companions.

Like in the Indian main-land, the Boro intellectuals that first emerged were the by-product of English education. Besides, conversion of a few English educated Boros into the Brahma religion also helped emergence of intellectuals in this community. They were the ones who first spread awakening among the Boros. In fact, the Boro intellectual that first emerged in the early $20^{\text {th }}$ century were mostly the Brahma converts. The first man that appears in the chronology of Boro awakening is Baba Kalicharan Brahma. 'Brahma' was the title given to him by the profounder of Brahmaism Sivnaranayan Paramahangsha, replacing his original title 'Mes.' Born in 1860, he completed Primary education and joined Middle School of the locality, which however he could not complete. Though he failed to acquire higher education, he had great concern for the growth and development of the Boro community. In fact, he became the first Boro personality to realize the need of reforming the Boro society. Like other reformer of the time, he too realized the need of reforming Boro society on the basis of western ideas of rationalism and human values. Realizing the fact that spread western ideas of science and rationalism alone could reform the Boro society, he strongly advocated for the spread of western education among the people of this community.

\section{The Early Boro Intellectuals and the Social Reformations}

Like any other pre-modern Indian societies, Boro society too had grown with number of socio-religious evil practices in it. Of all, polytheism, polygamy, marriage by forceful lifting, witch-craft, degeneration in the morale of the nationality, excessive use of intoxicants etc. were rampantly prevalent in the Boro society. Though the evils of Aryan casteism were yet to hold the ground, its advent into the region, spelled other disqualifications on the non-Aryan populations, particularly those who came into contact with the Aryan culture. Of all, the socially segregation between the Aryans and non-Aryans, or between Hindus and non-Hindus, identifying the later with the derogatory terms like 'untouchable', 'uncivilized', 'ill-mannered' (kuachri) etc. were damaging to the very morale of the ethnic communities. Many communities, living in Assam plains, where Aryan culture made its first advent in the $7^{\text {th }}$ century, became victims of this downgrading social system. The Boros were no less affected by the extension of the casteism Aryan culture. Their food habits, life style were looked down upon by the high caste Hindus so much so that they were considered 'Mes' or 'Mles', meaning untouchables, which

\footnotetext{
7 . A Gramci, op. cit. p. 5.

. L. N. Sharma, op. cit. Pp. 14-15.

9 . Sumit Sarkar, Modern India 1885-1947, New Delhi, 1983, p.65.

${ }^{10}$. Ibid, p. 65.

11. Bipan Chandra, Rise and Growth of Economic Nationalism in India, New Delhi, 1970, p. 752.

${ }^{12}$. Bipan Chandra, Nationalism and Colonialism in Modern India, New Delhi, 1979, Pp. 144-170.
} 
was the bottommost strata in the Brahmanical caste hierarchy. They were barred from social association with the higher caste, as well as, deprived of political participation. ${ }^{13}$ When such was the attitude of the caste Hindu Assamese, many Boros took conversion into Hinduism to escape the social depravity, as well as, with an expectation of rising in the ladder of caste hierarchy. The Census report of 1961 has large statistical figures, showing conversion of Boros and their rise in the caste hierarchy. ${ }^{14}$ Many Boros particularly, in the Dhubri SubDivision of the Goalpara District, took conversion into Islam as well. Such was the degree of derogation in the morale and dignity of the Boro community that bothered Kalicharan Brahma and his fellow social workers. Already polytheism, involving rituals, witch-craft and superstitious practices, excessive use of intoxicating drinks, lack of education and apathy to trade and business had made Boros a backward community. The task of emancipating this herd of People fell on Kalicharan Brahma and his followers. He found solace in Sivnarayan Paramahansha, whose religious Brahmaism preached monotheism, human love and dignity, far from the caste discrimination of Hinduism.

In the beginning of his career, Baba Kalicharan Brahma joined his father in business, who was a petty trader on timber. He continued the business on timber till 1930. Thereafter, he handed it over to his eldest son and dedicated himself for the propagation of Brahmaism and reformation of the Boro society. The prime concern of Kalicharan Brahma and his fellow intellectuals was to regenerate and restore the Boro society which had undergone centuries of derogation and depravity. Like other reformers of Indian main-land, he believed in the fusion of East with the West. He professed a religion based on the Eastern philosophy, whereas, proposed to reform the society, on the basis of western science and rationalism. He realized the fact that Boro society could be regenerated only by inculcating western ideologies of human equality, dignity and reason, through the spread of western education. With this objective in mind, he, with the financial grant received from the Government, opened three schools, at a place called Tipkai. The three schools, one English Middle School, one Weaving School and the other Carpentry School, started classes in 1913. He, along with the elders of the localities, made education compulsory for the Boro children. Guardians failing to send their children to schools were penalized with fines. ${ }^{15}$ At Dhubri, two hostels, namely, 'Brahma Boarding' and 'Mes Boarding' were constructed for the Boro students, perusing higher education. These hostels were constructed by the contributions of the landlords of the area. These schools were later on taken over by the Government. ${ }^{16}$ These hostels, particularly, the 'Brahma Boarding', produced quite a good number of progressive Boro intellectuals, who became faithful associates of Kalicharan Brahma, in his struggle for reforms and regeneration of the Boro society. In the later years, many of them emerged as prominent social workers and successful politicians. Rupnath Brahma, who held ministry in the state politics for several years, and noted social workers and educationists like Modaram Brahma, Promod Chandra Brahma, Satish Chandra Basumatari, Darendra Basumatari were a few among them. With the passage of time, the 'Brahma Boarding' became the centre of intellectual activities of the Boros. The idea of forming a literary organization originated from this very boarding. The students of this boarding, together with other like-minded Boro intellectuals, organized a 'Bodo-Club', which became the citadel of the Bodo Sahitya Sabha of the later years. ${ }^{17}$ This had undoubtedly been the manifestation of the Boro nationality consciousness, -- the fruits of the hard work of Baba Kalicharan Brahma and his associates. Another contribution of significance, fostering the nascent nationality consciousness, was the formation of the 'Boro Chatra Sanmelan' (Boro Students' Association) in 1919, under the guidance of Baba Kalicharan Brahma and with the active support of Rupnath Brahma and Modaram Brahma, who were students at that time. ${ }^{18}$ This laid the foundation for the formation of the All Bodo Students' Union in the 1970s.

Another organization of great importance was the convention of the 'Boro Maha Sanmelan' (All Boro Convention). The Convention had its annual conferences alternately in different districts of the state. The first annual conference, held at Bhawraguri, was presided by Jadav Chandra Khakhlari, and nominated Suryanarayan Brahma as the General Secretary of the convention. Two more annual conferences were held in the following years. The second conference was held at Rangia of Kamrup district and the third at Rowmari of Bongaigaon district. The Maha Sanmelan was constituted to become the major platform of the progressive Boro intellectuals, whose reforming sentiments, actuated into passing of resolutions and decisions for reformation of the Boro society. In the first conference, the Convention resolved to open Primary Schools in each and every Boro villages. Resolutions prohibiting use of intoxicating drinks, raring pigs, restricting expenditures in marriages and social ceremonies were passed. An executive committee was formed to oversee the enforcement of these resolutions in the society. ${ }^{19}$ Similar resolutions re-affirming the previous decisions were taken in the second and

\footnotetext{
13. Asom Sahitya Sabha, Gurudev Baba Kalicharan Brahma, 1983, the introductory part.

14. Census of India, 1961, Vol III, Assam Part V-A, rpt. of the Caste and Tribes of Assam from Chapter VI of the report of the Census of Assam, Pp. 8-30.

${ }^{15}$. Asom Sahitya Sabha, op. cit. Pp. 20-21.

${ }^{16}$. Ibid, p. 21.

${ }^{17}$. Khungkhra, An Introduction of the Mishings and the Bodos Kokrajhar, 1982, p. 26.

18. Asom Sahitya Sabha, op. cit. p. 22.

${ }_{19}$. ibid, Pp. 22-23.
} 
third conferences as well. Thus Kalicharan Brahma, together with his fellow intellectuals began a social movement for the regeneration of the Boro society. In the third conference of 1929, at Rowmari, a three thousand strong team of volunteers committed themselves to executing the resolutions, passed by the convention so far. Kalicharan Brahma, together with his associates, prepared a social code of conduct for the Boro Society. Five 'Asharas' or code for the trial and punishment were also prepared, which are still in use in the Boro areas of the state. ${ }^{20}$

Another aspect of Boro awakening was the inculcation of the idea of self-reliance particularly, in the field of economy. Opening of the weaving and carpentry schools were parts of their economic programme for the people of their community. Their expectation was that the weaving and carpentry schools, which were the first of its kind in the whole of Assam, would train the Boro youths in self employment and entrepreneurship. Their economic programme was further re-enforced by the opening of a 'Brahma Company', which extended consultation and financial assistance to the up-coming Boro traders. Every Boro individual could become a share-holder by investing in the company. The 'Brahma Company' made considerable progress within a short period of time. Shops were opened in different places with the investment made by the share-holders. The Company flourished and even expanded its trade to Bengal. ${ }^{21}$ But the Company lacked expertise management. As a result, its growth and subsistence came under threat within a short period of time, hardly surviving for a decade. Yet establishment of the 'Brahma Company' has great significance in the history of the Boros, in the sense that this had been the first, and knowledgeably, the last attempt to building up Boro economy on capitalist line, in an organized manner. Thereafter, no such attempt was made by the Boro intellectuals of the later years. The social reformers of this time also encouraged the Boros to trade on the agricultural products, which were easily available to them. Kalicharan Brahma, who himself was a trader on timber, greatly encouraged people to take up trade and business. He was convinced that only trade and business could build up the economy of an individual and of the community. On the whole, Kalicharan Brahma desired the people of his community to build up their economy on capitalist line, trough trade and business, which, he considered to be the surest means for economic development.

\section{Social Reformers to Political Leaders}

By the end of 1920s, the Boro intellectual had grown in number and consequently in the strength as well. Towards the end of this decade, their interests were seen drifting from socio-economic reformation to politics. The coming of the Simon Commission in 1927 provided the necessary springboard for their switchover. The Simon Commission reached Assam in 1928 and remained functional in the state till January, 1929. The objective of this Commission was to inquire into the working of the system of Government, the growth of education, and development of representative institutions in British India and to report as to whether and to what extent; it was desirable to establish the principle of responsible Government. The Royal Notification served throughout the Indian Domain in March 6, 1928, called for memoranda, to be submitted to the Commission. The Boros too, submitted memoranda through different organizations of their community. Baba Kalicharan Brahma led the delegation team of the Goalpara District Community, while Jadav Khaklari submitted another memorandum as the Secretary of the Assam Kachari Juba Sanmelan, on behalf of the entire Boro community of Assam. ${ }^{22}$ The memoranda urged the Government to grant a separate electorate for the Boro-Kachari community, both in the Assembly and local board elections; to provide compulsory free primary education to the students of this community. The memoranda also appealed the Government not to transfer Assam to Bengal province and recommended for a single chamber ministry for Assam. ${ }^{23}$ The memoranda submitted by the Boro-Kachari organizations however did not receive due response from the Government. Intellectuals, who have gone through the original report of the Commission sense foul-play by an Assamese member, who was entrusted with the responsibility of receiving the memoranda from the organizations. ${ }^{24}$ However, the memorandum submitted by the Provincial Government redressed Boro grievances to some extent. ${ }^{25}$

Despite initial disappointment, the visit of the Simon Commission opened up a new vista of political venture for the Boro intelligentsia. Submission of the memoranda had already shown the degree of their political consciousness. Their political aspirations grew even more when the Government of India, announced its decision to reorganize the administration of India on the principle of self-government and provincial autonomy. A group of Boro intellectuals prepared themselves to share the outcome of the recommendations of the Simon Commission. They, together with other plains tribal leaders, formed a political organization known as the Tribal

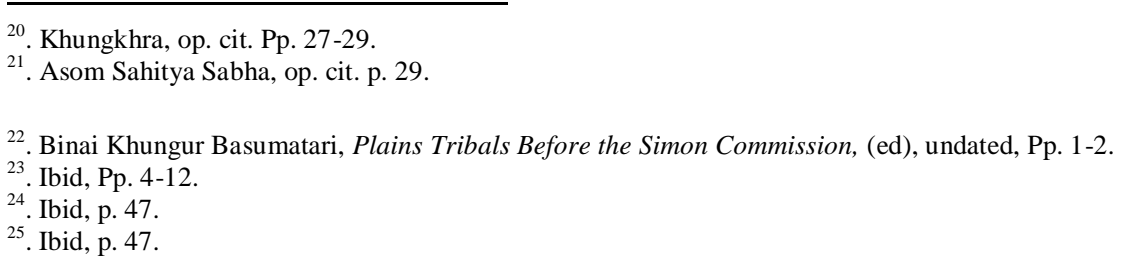


League in 1933, to participate in the forth-coming election. The Tribal League remained the only political platform of the plains tribals till its transformation into a socio-cultural organization after the Independence. Meanwhile the Indian Act of 1935 announced 5 (five) reserved seats in the State Assembly for the plains tribals. After the 1937 election, the Tribal League formed coalition Governments, once with the Assam Pradesh Congress Committee in 1939, and the other with the Assam Muslim League in 1940. The prime objectives of the League leaders, majority whom were the Boros, were to secure constitutional safeguard of the economic and political interests of the plains tribal communities through the continuance of the separate electorate for them, to constitute reserved constituencies and to treat all the tribals, irrespective of their religions, as one separate class. ${ }^{26}$ Though the Tribal League emerged as on of the major political party in the state, whose extension and withdrawal became detrimental to two coalition Governments of 1939 and 1940, its leaders appeared to have been contended with the constitutional safeguard of tribal interests alone. This may be read from their decision to remain under Assam, even without securing any administrative autonomy. The tribal political leaders appeared to have expected to redress their grievances through direct participation in the politics of the country.

After the Independence, the League leaders transformed the Tribal League into a socio-cultural organization known as the 'Tribal Sangha', thinking that the Independences would address their grievances without having to go for political movements ${ }^{27}$ Boro leaders like Rupnath Brahma, Dharanidhar Basumatari, Rabindra Kachari and others joined Congress, and were able come to the political forefront of the State. However, their success alone was not enough to address the growing grievances of the Boros, nor it was possible for them to bridle the up-coming tribal aspirants who would now like to share the front-stage of the tribal politics. The differences hitherto under current raised its head in 1946, when conflict arose over the nomination of candidate for the Parliamentary election. The Boro Congress leaders nominated Dharanidhar Basumatari, while the opposing group nominated Bhimbor Deuri for the same Kokrajhar Parliamentary. ${ }^{28}$ This conflict had however no immediate effect on the plains tribal politics of the state. But it undoubtedly indicated the diversion in the future course of Assam politics.

As time passed by, the differences between the opposing groups grew, particularly, when the tribal legislatures failed to achieve anything substantial to ventilate the grievances and aspirations of their people. On the contrary, within a short period of time, there had been erosion in whatever little accommodation of tribal interests, done by the pre-Independence election agreement. The grievances and aspirations brew with the passage of time, opening new avenues of political venture for the up-coming tribal politicians. The formation of the Plains Tribals Council of Assam (PTCA) in 1967 was the off-spring of this development. The new organization set a goal of securing political solution to their grievances and aspirations. It was easy for the new party to mobilize the disgruntled leaders and masses to their side. Their active support made the Plains Tribals Council of Assam one of the major political parties of the state within a few years. So also was the vigor and spirit of the leaders, who, in many occasions, mobilized the masses into large scale agitations in favor of their demands. But their commitment and steadfastness fast disappeared. In the 1970s, they began drifting from their original demand, often baiting the very demand for their political ambition. ${ }^{29}$ Such attitude of the Council leaders gave rise to the later political developments. Particularly, in the last three decades of the $20^{\text {th }}$ century, a number of political organizations joined the political arena of the State. Results were nothing but the telltales of rivalries, chaos and confusions among the Boros.

\section{Literatures and Literary Activities}

The emerging Boro intellectuals expressed themselves in the literatures of their times. Though scanty in the beginning, they grew out of sheer necessity and with spontaneity, unaided by any previous literary citadel. They were the products of historical, social, political and cultural necessities, coupled with Boro intellectuals urge to give vent to their creative talents. The literature of this period consisted of journals, periodicals and souvenirs which were published to commemorate different occasions. The major theme of the early literary works was the exposition of the backwardness of this community as well as eradication of the social evils prevailing in the Boro society, together with inculcation of self-consciousness by highlighting the ancient glory of this nationality. ${ }^{30}$

The Boro literatures of the early period were the creation of the social reformers themselves. Hence, their writings primarily aimed at socio-economic and political uplift of their people. The educated Boros,

\footnotetext{
${ }^{26}$. The text of the agreement concluded between the Tribal League and the Assam Congress Committee dated $10^{\text {th }}$ September, 1939, Shillong and the text of the agreement between the Tribal League and the Assam Muslim League, dated $16^{\text {th }}$ March 1940, Shillong.

${ }^{27}$. Parag Kumar Das, Prantik, July 16-31, 1983, p. 16.

${ }^{28}$. Ibid, p. 16.

29. During the Janata regime, the leaders of the Plains Tribals Council of Assam gave up their demand to become a coalition partner in the ministry of the State.

${ }^{30}$. M. R. Lahiry, 'Early History of Bodo Literature; in the Souvenir, published by the Bodo Sahitya Sabha, Korajhar, 1984, Pp. 1-2.
} 
professing Brahma religion, played a significant role in this sphere. In fact, the literatures of this period were the works of a small band of Boro students who were the Brahma converts. ${ }^{31}$ Thus, coming of Brahmaism, despite certain negative impacts, was a blessing to the Boro community. It produced a group of progressive Boro intellectuals who dedicated themselves for the reform and uplift of the Boro society.

The foundation of the 'Brahma Boarding' at Dhubri and opening of schools at different places have already been mentioned. It has also been noted that these boardings and educational institutions were the breeding grounds of Boro intellectuals who took up reformation in their society. Particularly, the students of Dhubri Brahma Boarding made significant contribution in this field. For instance, they were the ones to bring out the first Boro journal Bibar in 1924. Edited by Satish Chandra Basumatari, this journal, received patronage of persons like Rupnath Brahma, Daren Basumatari and others, who are now considered as the pioneers and elevators of the Boro society. The students of this boarding also founded a literary organization called the 'Bodo Club. ${ }^{32}$ Thus the genesis of the Boro literature was set by the students of the Dhubri Brahma Boarding.

The early decades of the $20^{\text {th }}$ century were the years of hectic efforts to revive the Boro culture and literature, followed by social as well as political reformations initiated by Baba Kalicharan Brahma. In these years, backed by a host of Boro social reformers, Baba Kalicharan Brahma, launched crusade against the evil practices embedded in the Boro society, as well as, against the socio-political discriminations meted out to the Boros. Touched by the reforming zeal, the Boro authors of this time, tried to regenerate the society through their thematic dramas, articles and poetries etc. Among the dramatists, who made significant contributions to the Boro literature and society, the names of Mr. Darendra Basumatari, Satish Chandra Basumatari, Modaram Brahma, Nobin Brahma and Maniram Iswari may be duly mentioned. The dramas like Nilambar and Sukharu Dukharu, written by Mr. Darendra Basumatari, Darshan Jwhwlao and Rani Laimuthi, by Satish Chandra Basumatari, Dimapur Nogor Bainai, Raimali, and Sodang Bwiragi by Modaram Brahma, Dhantri Palla by Nobin Brahma, Rangalu Jwhwlao by Promod Chandra Brahma and Domshu Gudiao by Lal Mohan Brahma. It is to be noted that the dramas mentioned above were not printed; they are still in the form of manuscript, and as such they cannot be regarded as regular literature. But the fact that they were the creations of the pioneering Boro authors, with fine gems of literature in them, vouches for them a place of significance in the chronology of Boro literature.

In the chronology of Boro literature, the poetry appeared to have preceded the prose. For instance, the Khonthai Methai, which is a collection of poems, published in 1923, appears to be the first printed Boro literature. The poems compiled therein were contributed by Modaram Brahma, Rupnath Brahma, Satish Chandra Basumatari, Ratiram Brahma and Suren Brahma. Close to the heel of the Khonthai Methai was another book of poems Gudi Sibsa Aro Aroj, which was composed by Modaram Brahma and published in 1926. Edited by P. C. Brahma and published in 1924, the Hathorkhi-Hala was another great collection of poems, contributed by Iswan Mosahari, Anandaram Mosahari, Kali Kumar Lahari, Munindra Champramari and P. C. Brahma himself. The poems compiled therein are the examples of great poetic creation of that time. Particularly, the poems composed by Iswan Brahma, who, with all his romanticism, is often regarded as the John Keats of Boro literature, gave the best of his poetic imagination. His poems compiled in Phami, are the greatest Boro poems of that time and they stand out as par excellence even this day. The Gudi Sibsa Aro Aroj was followed by the publication of the popular Boro journal Bibar. Published in 1924, the Bibar becomes the second in the chronology of Boro literature. But the Bibar, with its varieties in content, became popularity among the literate circles of the community. This journal was edited by Satish Chandra Basumatari, who was one of the founder members of the Tribal League, formed in 1933. The Bibar, with all its popularity, became the mouth-piece of the emerging Boro intellectuals. Besides giving vent to the creative talents of the Boro intellectuals, this journal became instrumental in voicing the sentiments of the Boros who were increasingly under the threshold of sociopolitical consciousness by then. Reports, speeches, resolutions, decisions and guidelines, infested with the sentiments of reviving their ancient glories, reforming the society or establishing their community as par other advanced communities around etc. were published in this journal. Looking at the popularity and pre-eminence of this journal, critics have named the period between 1924 and 1940, as the Bibar Age,--a name given after the journal Bibar. ${ }^{33}$ The critics of Boro literature thus regard Bibar as the first mile-stone of Boro literature. This journal was followed by large number of literary works, both in the forms of prose and poetry. The important magazines of this period were Jenthokha, edited by Satish Chandra Basumatari, Olongbar, edited by Promod Chandra Brahma and Nayak (1942), edited by M K Brahma and Jogen Hazarika. Though most of the Boro authors and contributors were the beginners at that time, their writings appear to have had great value so far as the situation and sentiment of the community were concerned. They were the expressions of the emerging

\footnotetext{
${ }^{31}$. Publication of Bibar, the first Boro journal was the work of the Boro students, converted into Brahmaism.

${ }^{32}$. Biren Das Boro, 'Boro Sahityar Itihas' (Hitory of Boro literature)in Songrai, Bodo Sahitya Sabha, Korajhar, 1985, Pp. 43-44. ${ }^{33}$. Ibid, p.45.
} 
subjective self-consciousness, goaded by the prevailing objective conditions rooted in the socio-economic and political situations of the community.

The literary works of this period, acted as a two edged sword for the Boro community. The creative talents of the Boro writers contributed the growth of the Boro language and literature, at the same time; they became instrumental for the inculcation of socio-economic and political consciousness among the members of this community. Through Bibar, they raised the sentiment of reviving their ancient glory. The speeches of Rupnath Brahma, given on the origin of the Boros appeared in the Nayak. Another journal Lirthum Bilai was also devoted to the cause of the Boros. ${ }^{34}$ Various writings, published in Boro journals, magazines and Souvenirs appealed the sentiment of the Boro students, who, in turn, adopted measures for the betterment of the society which consequently generated self-consciousness among the members of this community. Parsuram Brahma's article 'Jatya Sahitya', published in Bibar had already emphasized on the need of having a national literature of the Boros themselves. ${ }^{35}$

The formation of the Bodo Sahitya Sabha on November 16, 1052, which was an offshoot of the 'Bodo Club' mentioned above, may be considered as a significant achievement of the Boro intellectuals. Its formation heralded a new era in the history of Boro literature. In fact, with the formation of the Sahitya Sabha, the Boro awakening transformed itself into a movement for linguistic identity. It formulated programmes which were primarily guided by their search for a separate identity or often in response to the challenges poised by the Assamese counter. The post 1952 Boro search for linguistic identity was invariably accompanied by Boro intellectuals' fear for Assamese domination. For instance, Bodo sahitya Sabha's move for the introduction of Boro as the medium of instruction in the schools of Boro dominated areas was launched on the backdrop of Assamese language movement of 1960. Ultimately, Boro language was introduced as the medium of instruction in the Boro majority areas in $1963{ }^{36}$ Likewise, the Sahitya Sabha responded to the Assamese language movement of 1972, launching agitation for Roman script for the Boro medium schools. Though the movement ended in the acceptance of the Devanagari script, Boro intellectuals appeared to have been more consoled rather than falling back on the Assamese script, which had hitherto been in use. in the Boro medium schools. With this sentiment in their minds, the Boro intellectuals continued their language movement. In 1977, after prolonged agitation, Boro was declared as one of the Major Indian Languages, to be taught in the colleges under the Gauhati University. Then came in 1985, the much awaited declaration from the State Government recognizing Boro as an Associate Official Language of the State. ${ }^{37}$ Yet another achievement was made in February 10, 2003, when by the terms of the Bodoland Territorial Council Accord, Boro language was included in the Eight Schedule of the Indian Constitution. ${ }^{38}$

\section{Conclusion}

The Boro intelligentsia began emerging in the beginning of the $20^{\text {th }}$ century, with its roots in the Government services and with predominant connection with land. They were a few English educated Boros, who, transpired by the western ideas of science and rationalism felt it essential to redeem the Boro society from its pre-modern social disqualifications. Relational social exclusion caused by the advent of Hinduism, irrational practices and habits, lack of modern education and total apathy to the capitalist economy were a few of the multiple disqualifications which drew the reforming minds of the Boro intelligentsia of that time. The Boro intellectuals of the early $20^{\text {th }}$ century organized themselves into different bodies and unions and formulated a social code of conduct banning all kinds of evil practices. With an idea of heralding intellectual awakening, they opened schools in different Boro populated areas and made education compulsory for the children. Parents failing to send their children to the schools were punishable by fines. They also attempted to imbibe the idea of building a self-sufficient Boro society by taking up trade and business. They founded a few financing companies, which were, however, shot-lived. Thus, the early Boro intelligentsia set the idea of Boro selfconsciousness in motion which was to be taken up by the later intellectuals with greater vigour and momentum. By 1930s, the Boro intelligentsia had gained enough ground, so also the situations, social and political, of then Assam changed to complicated ethnic cleavages and conflicts. The coming of the Simon Commission promising self-governance and autonomy, boasted up the ethnic elites to organize themselves to reap the share of the upcoming reforms. It was at this juncture that many Boro intellectuals, so far engaged in the social reforms, transformed themselves into political leaders. In the following decades, of both pre and post-Independence times, many of them were able to identify themselves with the ruling elites, who, however failed to fully represent the interests and aspirations of the Boro masses. Like in any other societies, the Boro intellectuals

\footnotetext{
${ }^{34}$. M R Lahiry, op. cit. Pp. 4-5.

35 . Ibid, p. 4. (English section).

36. The Telegraph, May 19, 1963.

${ }^{37}$. The Sentinel, April 5, 1985.

38. The Telegraph, February 11, 2003.
} 
made commendable contribution to the growth of Boro language and politics. However, true to the elitist characteristics, the Boro intellectuals too, drifted time and again, even at the cost of their own people. Their steadfastness in the Roman script movement of 172-75 and in the ongoing political movement has often come under scanner. However, history has such numerous examples of intellectuals or elites playing dubious role in the process of social development. Same has been the case with the Boro intelligentsia.

\section{References}

[1]. Asom Sahitya Sabha, Gurudev Baba Kalicharan Brahma, Gauhati, 1983.

[2]. Basumatari, Binai Khungur, Plains Tribals Before the Simon Commission, (ed), Harisinga, undated.

[3]. Basumatari, J. K, 'Boro Sahitya Sabhani Sungdoh Jarimin', (A Brief History of the Bodo Sahitya Sabha), In Souvenir, published by the Bodo Sahitya Sabha, Kokrajhar, 1984.

[4]. Brass R. Paul, Ethnicity and Nationalism Theory and Comparison, New Delhi, 1991.

[5]. Boro, Biren Das, 'Boro Sahityar Itihas' (History of Boro literature), in Songrai, Bodo Sahitya Sabha, Kokrajhar, 1985.

[6]. Bottomore, TB, Elites and Society, Penguin Publication, 1964.

[7]. Census Of India, 1961, Vol III, Assam Part V-A, rpt of the Castes and Tribes of Assam, from chapter IV of the report of the census of Assam.

[8]. Chandra, Bipan, Nationalism and Colonialism in Modern India, New Delhi, 1979.

[9]. Chandra, Bipan, Rise and Growth of Economic Nationalism in India, New Delhi, 1970.

[10]. Das, Parag Kumar, 'Asomor Janajatya Raijor Somoisya, Udayachal aru Annainya' (Problems of the Tribals of Assam, Udayachal and etc.) In Prantik, July 16-31 issue, 1983.

[11]. Hare, Quiton \& Nowel Smith, Geoffrey (ed), Selection from Prision Notebooks of Antonio Gramci, London, 1971.

[12]. Khungkhra, An Introduction of the Mishings and the Bodos, Kokrajhar, 1982.

[13]. Lahiry, M.R, 'Early History of Bodo Literature' in Souvenir, published by Bodo Sahitya Sabha, Kokrajhar, 1984.

[14]. Prabhakar, M.S., 'The Politics of Script' in the Economic and Political Weekly, December 21, 1974.

[15]. Sarkar, Sumit, Modern India, 1885-1947, New Delhi, 1983.

[16]. Sharma, L N, 'The Theories of Elites, Importance and Relevance', in Elites and Development, (ed), by sachidananda \& AK Lal, New Delhi, 1980.

[17]. The Kokrajhar District Bodo Sahitya Sabha, Struggle for the Bodo Language. Kokrajhar, 1968. x

[18]. The Sentinel, April 5, 1985.

[19]. The Telrgraph, May 19, 1963 and February 11, 2003.

[20]. The Text of agreement concluded between the Tribal League and the Assam Congress Committee dated September 10, 1939, Shillong and the text of agreement between the Assam Muslim League and the Tribal League, dated $16^{\text {th }}$ March 1940 , Shillong. 